\title{
DOI https://doi.org/10.30525/978-9934-26-042-1-26
}

\section{КОНКУРЕНТНІ ЗАСАДИ МЕДІЙНОГО РИНКУ}

\author{
Шальман Т. М. \\ доцент кафедри реклами та зв'язків з громадськістю \\ Інститут журналістики Київського національного університету \\ імені Тараса Шевченка \\ м. Київ, Украӥна
}

Медійний ринок відчутний до тих змін в економічній системі, що відбуваються у третьому тисячолітті. Певним чином відходить у минуле індивідуальна приватна власність на медіа-носії. На зміну цій системі власності приходить корпоративна організація власності. У такій економічній системі видозмінюється конкуренція на медіаринку. Подібно до ринку будь-якої іншої галузі, що розвивається, за визначенням багатьох дослідників економічної науки на медіа-ринку спостерігається три види конкуренції: внутрішньогалузева, міжгалузева та міжнародна конкуренція.

Внутрішньогалузева конкуренція характерна для учасників медіаринку однієї галузі, тобто між тими компаніями, що виготовляють подібний інформаційний продукт: телепродукт, радіо продукт, друковану продукцію, цифрову інформаційну продукцію тощо. Цей вид конкуренції зумовлює учасників медійного ринку встановлювати відповідні «правила гри», визначати вартість власного товару, боротися за цільову аудиторію та рекламодавців на внутрішньому ринку.

Міжгалузева конкуренція на ринку мас-медіа $є$ більш складною, оскільки передбачає, що потужні мас-медійні корпорації ведуть конкурентну боротьбу за контроль над частиною мас-медійного сектора для вдалих капіталовкладень. 3 огляду на це, постійно відбувається перехід капіталу з менш прибуткових сфер (приміром, регіональних), до більш прибуткових. Як правило, саме ці процеси впливають на цінову категорію у мас-медіа.

Міжнародна конкуренція відбувається між виробниками інформаційного продукту, який виробляється для міжнародного ринку мас-медіа. За останні десятиліття зросла чисельність медійних об'єднань, що працюють на світовому ринку.

У медійному просторі України вітчизняні засоби масової конкуренції, виконуючи важливу місію у формуванні громадської думки в суспільстві, залишаючись певним чином масовими та 
доступними, все ж не встигають реагувати на нові інформаційні потреби та запити, які генерує сучасний соціум у світі та в Україні. У свідомості багатьох журналістів, видавців, менеджерів засобів масової інформації домінуе сприйняття медіа не як інструменту комунікації та впливу на суспільну свідомість, а як певну структуру бізнесу. Власники ЗМІ, керуючись правилом: «Той хто володіє інформацією - володіє світом», потрапляючи до еліт, «беруть у свої руки» засоби інформаційного впливу. Ні для кого не секрет, що єдиний інформаційний простір в Україні на сьогодні відсутній.

У столиці сконцентровані більш потужні ЗМІ. Регіони живуть своїм життям, яке описується власними ЗМІ, менш впливовими. У Києві не читають регіональну періодику і не дивляться регіональні телевізійні канали. 3 одного боку, в Україні зареєстровано близько 20 тисяч газет i журналів, близько двох тисяч телеканалів, тобто вибір джерел інформації величезний. Але якісного вітчизняного інформаційного продукту - все ще немає, а ті рідкісні винятки, які іноді радують читача або глядача, - лише підтверджують загальне правило. Кількість і якість доступних газет, каналів телебачення та радіо для жителя столиці на порядки вище за об'єми доступних носіїв інформації для жителя периферії. Спостерігається процес глобального розриву між верствами населення в середині українського суспільства.

Завдяки інформаційній діяльності засобів масової інформації, яка має надалі незмінно зростати й посилюватися, впливати на всі сфери життєдіяльності суспільства і держави, українські ЗМІ повинні стати інструментом впливу на розвиток комунікації між елітами та суспільством, виконуючи основне завдання - відповідати українським національним інтересам, сприяти утвердженню незалежної держави Україна. Тому дослідження інструментів впливу ЗМІ на розвиток комунікації між елітами та суспільством є доцільним і своєчасним.

В Україні ще не до кінця усвідомили той факт, що у сучасному світі змінюється сама типологія роботи ЗМІ. Вони перестають бути «масовими», адже на місці масового споживача з'являються, відносно автономні та орієнтовані на свої потреби, мережеві структури. Навіть виборчі кампанії та виборчі технології, які розкручуються на заході, демонструють, що це вже не просто маніпулятивні технології, а такі, що здатні ефективно використовувати потенціал мережевих структур. Саме на роботу 3 мережевими структурами починають витрачати левову частку передвиборчих бюджетів, щоб довести позиції того чи іншого кандидата до громадськості. Відомий фахівець у галузі масових комунікацій Лизанчук В. [2] зазначає: «...людські спільноти творяться мережами інформаційних комунікацій, через які передається необхідна державно-політична, суспільно-економічна, ідеологічна, історична, 
етнічна та інша інформація. Національна мережа засобів масової комунікації - це один із «трьох китів», на якому базується державна самосвідомість, поряд 3 національною інтелігенцією та національною політичною елітою».

Рівень комунікації, створений засобами вітчизняних медіа не на найвищому рівні. Складається ситуація, коли кожна 3 еліт прагне створити свій власний інформаційний простір або власний комунікаційний ресурс. Тобто, тепер людині не достатньо купити одну газету чи переглянути випуск новин на одному лише телеканалі, щоб отримати повну інформацію про те, що відбувається в країні чи світі. Це свідчення того, що наші медіа не готові виконувати комунікативну місію. Варто відзначити, що належна комунікація особливо відсутня між інтелектуальною та владною елітами.

Владній еліті переважно байдуже те, що думають та пишуть інтелектуальні лідери, а самим інтелектуальним лідерам важко й інколи нецікаво говорити щось через інформаційний простір тим, хто при владі. Таким чином, зараз велика частина інтелігенції існує окремо від влади й їхні таланти, знання, вміння та досвід абсолютно владі не потрібні, а псевдо-інтелектуали, які консультують владу, не зацікавлені в конкуренції ідей i тому навіть часто штучно обмежують потік інформації до еліти. Звісно, це напряму позначається на якості інформаційного простору.

Приміром, телевізійні передачі швидше розважають, ніж інформують, в основному поширюючи чутки, скандальні повідомлення, секс і насильство. Політичні програми в основному стосуються персоналій політиків або їх позиціонування, a не їх ідеологій. Але коли немає серйозного обговорення проблем, аудиторія залишається в заручниках у політичної пропаганди, що містить безглузді гасла, а це позбавляє іiі інтересу до політики і переповнює цинізмом. «Приватне комерційне телебачення підкоряється жорстким законам ринку, i, перш за все, принципом конкурентної боротьби, який змушує телемовників перебувати у постійному пошуку нових телевізійних форм, технічних хитрувань для того, щоб утримати телеглядачів біля свого каналу» [1].

Новини відбираються мас-медіа не за їх важливістю для суспільства, a за «комерційною» привабливістю i можливістю бути вигідно «проданими» цільовій аудиторії. У той же час, стрімкий розвиток інформаційних технологій, поява новітніх медіа, зокрема Інтернету, докорінно видозмінюють інформаційний простір. Темпи зростання доступу до Інтернету в Україні достатньо швидкі, і через декілька років ця проблема буде повністю вирішена. Коли всі люди матимуть доступ до Інтернету, то неможливо буде такими незграбними методами, які 
використовувалися раніше, маніпулювати свідомістю суспільства, приховувати від нього будь-яку інформацію, або ж дозувати іiі.

\title{
Література:
}

1. Свсейцева О. С. Аналіз медійного ринку України / О. С. Євсейцева, Г. М. Собцева. // Ефективна економіка. - 2016. № 5. - Режим доступу: http://nbuv.gov.ua/UJRN/efek_2016_5_45.

2. Лизанчук В. Феномен невмирущості нації // Наукові записки АН ВШ України. - 2004. - Вип. 6, 9-29. - С. 74-81.

\section{DOI https://doi.org/10.30525/978-9934-26-042-1-27}

\section{ІДЕОЛОГІЯ В МЕЛОДРАМІ: ТЕЛЕСЕРІАЛ «САГА»}

\author{
Яблонський М. Р. \\ старший викладач кафедри соиіальних комунікацій \\ Волинський національний університет імені Лесі Украйнки \\ м. Луиьк, Україна
}

Беззаперечним $\epsilon$ вплив телепродукції на широку аудиторію, тим більше, коли мова йде про жанри художнього фільму. Телесеріал як зразок масової культури займає особливе місце, адже, будучи тривалим у часі й залучаючи різну за віком та ідейними й естетичними вподобаннями аудиторію глядачів, має перспективу широкого резонансу. Оцінка може бути полярно протилежною не лише через різні засади. I пересічний глядач, і фаховий критик (i не тільки мистецтвознавець, бо літературознавець оцінить сценарій (а часто основою слугує художній твір), мовознавець - лінгвістичні аспекти, історик та політолог - відповідність духу часу, психолог - конфліктні ситуації, поведінкові типи, презентовані героями, специфіку сприйняття глядачами, медіазнавець із врахуванням цих думок у комплексі простежить соціокультурні та ідеологічні процеси в комунікативному ключі) розглядають явище ще й з огляду на свій життєвий досвід.

Об'єктом нашої уваги є телесеріал «Сага» (2020; автори сценарію: Т. Гнєдаш, I. Чернова, Н. Нікішина, за участю С. Бургели; режисер Д. Лактіонов; 12 серій). Предмет дослідження - специфіка реалізації ідеологічних завдань у мелодрамі. 